Yilmaz Bayar*

\section{Macroeconomic, Institutional and Bank-Specific Determinants of Non-Performing Loans in Emerging Market Economies: A Dynamic Panel Regression Analysis}

\begin{abstract}
Banking sector is important for various macroeconomic and microeconomic variables in terms of mobilization of funds, increasing savings, and providing alternative investment instruments suited to the every person by minimizing the risk of adverse selection and moral hazard, allocating funds to most productive projects, risk diversification. Therefore, sound functioning of the banking sector is critical especially for emerging and developing countries. This study explores the macroeconomic, institutional, and bank-specific factors behind nonperforming banking loans as an indicator of banking sector functioning in emerging market economies over the 2000 2013 period by employing the system GMM dynamic panel data estimator. Results of the dynamic panel regression analysis showed that economic growth, inflation, economic freedom (institutional development), return on assets and equity, regulatory capital to riskweighted assets, and noninterest income to total income affected nonperforming loans negatively, while unemployment, public debt, credit growth, lagged values of nonperforming loans, cost to income ratio and financial crises affected nonperforming loans positively.
\end{abstract}

Keywords: Non-performing loans, macroeconomic factors, institutional factors, bank-specific factors, economic freedom, credit risk, emerging market economies

JEL Classifications: C23; E60; G21; G28; G32
${ }^{*}$ Usak University,

Faculty of Economics and

Administrative Sciences,

Turkey

E-mail:

yilmaz.bayar@usak.edu.tr 


\section{Introduction}

Financial system contributes to the economic growth through affecting the decisions of saving and investment by providing alternative investment instruments suited to the individuals, mobilization of the savings, risk diversification, efficiently allocation of the funds to the best uses (Petkovski and Kjosevski, 2014). Financial system has still been dominated by banking sector especially in emerging and developing markets, although the structure of the financial system varies from country to country. So the share of bank based-financing is much more than market-based financing in the financial system in both emerging markets and developing countries. In this regard, health, stability and soundness of the banking sector exhibits importance for the health of all the other economic units. Therefore, attention should be paid and policy-makers should avoid following institutional and economic policies which endanger banks.

One of the most monitored critical indicators is nonperforming loans (NPL) which reflect the loan quality of banks. Sharp increases in NPL have a potential to cause deteriorations in the functioning of banks through affecting their liquidity and profitability, even leading to bank failures and banking crises in the advanced stages. As a consequence, banks can tighten the lending standards and/or loans and in turn affect the economic activity negatively by way of credit crunch (Stijepović, 2014). So NPL minimization is among the priorities of regulators and policy-makers. NPL minimization requires interested parties to comprehend the determinants behind NPL in order to evaluate the impact of alternative policies on NPL and to monitor NPL.

Emerging market economies such as China, India and Poland have experienced considerable growth rates and improvements in their financial sectors and other macroeconomic indicators. This study explores the macroeconomic, institutional, and bank-specific determinants of NPL in emerging market economies during the 2000-2013 period by employing the system GMM dynamic panel data estimator. It will endeavour to contribute to the existing literature, because it is one of the first studies investigating the determinants of NPL for the emerging market economies by using a model consisting of macroeconomic, institutional, and bank-specific factors with economic freedom and a dynamic estimator. In this context, the next section overviews the theoretical and empirical literature, Section 3 presents data and econometric methodology, and Section 4 conducts empirical analysis and communicates major findings. Section 5 concludes the study. 


\section{Literature Review}

External factors such as macroeconomic and institutional environment in which banks operate and internal factors consisting of bank management, loans volume, capital adequacy ratio, bank profitability, and lending rates are the major causes behind NPL because macroeconomic environment has a heavy hand on the solvency of borrower, while institutional environment is important for efficient functioning of the financial system. Finally, bank-specific factors such as assets and debt composition, capital structure, risk management and profitability of banks are important for the size of NPL.

A great number of empirical studies researched the determinants behind NPLs employing regression analysis and time series analysis on a country or a group of countries basis. In the part of literature review, the findings of the selected recent major papers will be summarized in Table 1, taking account of extensive studies in this field. Table 1 indicates that economic growth, income per capita, savings, institutional development, bank capital and return on assets/equity had negative impact on NPL, while unemployment, foreign exchange (direct quotation), lending interest rate, public debt, corruption, operating inefficiency, credit growth, crises and lagged values of NPL had positive impact on the NPL.

In one of the recent studies from the relevant literature, Boudriga et al. (2010) researched the determinants of NPL in 46 banks of 12 MENA countries during the period 2002-2006 and revealed that credit growth rate, return on assets had, foreign participation from developed countries, voice and accountability, regulatory quality, rule of law and control of corruption had negative impact on NPL, while lagged loan loss provisions had positive impact on NPL. On the other side, Louzis et al. (2012) investigated macroeconomic and bank-specific determinants of NPL in Greece during the period 2003Q1-2009Q3 by using dynamic panel regression and they found that economic growth had negative impact on NPL, while unemployment, real lending interest rate, public debt and bad management had positive impact on NPL. On the other hand, Swamy (2012) examined the macroeconomic determinants of NPL in India using panel regression during the period 1997-2009 and found that industrial production, income per capita, savings growth rate, bank assets, credit deposit ratio, cost of funds, priority sector loans to total loans had negative impact on NPL, while operating expenses to total asset and return on assets had positive impact on NPL. 
Table 1: Literature Review about Determinants of Bank Non-performing Loans

\begin{tabular}{|c|c|c|}
\hline Variables & Impact & Studies \\
\hline $\begin{array}{l}\text { Economic } \\
\text { growth, industrial } \\
\text { production }\end{array}$ & Negative & $\begin{array}{c}\text { De Bock and Demyanets (2012), Louzis et al. (2012), Curak et al. (2013), } \\
\text { Ahmad (2013), Messai and Jouini (2013), Makri et al. (2014), Skarica (2014), } \\
\text { Tanasković and Jandrić (2015), Roman and Bilan (2015), Ghosh (2015), } \\
\text { Kjosevski and Petkovski (2016), Koju et al. (2018) }\end{array}$ \\
\hline Income per capita & Negative & Swamy (2012), Ghosh (2015) \\
\hline Savings & Negative & Ahmad (2013), Koju et al. (2018) \\
\hline \multirow{2}{*}{ Inflation } & Negative & Roman and Bilan (2015) \\
\hline & Positive & Curak et al. (2013), Klein (2013), Skarica (2014), Ghosh (2015) \\
\hline Unemployment & Positive & $\begin{array}{l}\text { Louzis et al. (2012), Messai and Jouini (2013), Klein (2013), Makri et al. } \\
\text { (2014), Skarica (2014), Roman and Bilan (2015), Ghosh (2015), Kjosevski and } \\
\text { Petkovski (2017) }\end{array}$ \\
\hline $\begin{array}{l}\text { Foreign exchange } \\
\text { (direct quotation) }\end{array}$ & Positive & De Bock and Demyanets (2012), Klein (2013), Tanasković and Jandrić (2015) \\
\hline \multirow{2}{*}{$\begin{array}{l}\text { Lending interest } \\
\text { rate, real interest } \\
\text { rate }\end{array}$} & Positive & $\begin{array}{l}\text { Louzis et al. (2012), Messai and Jouini (2013), Curak et al. (2013), Abdioglu } \\
\qquad \text { and Aytekin (2016) }\end{array}$ \\
\hline & Negative & Ahmad (2013) \\
\hline Public debt & Positive & Louzis et al. (2012), Makri et al. (2014), Ghosh (2015) \\
\hline $\begin{array}{l}\text { Voice and } \\
\text { accountability }\end{array}$ & Negative & Boudriga et al. (2010) \\
\hline Regulatory quality & Negative & Boudriga et al. (2010) \\
\hline Rule of law & Negative & Boudriga et al. (2010) \\
\hline Corruption & Positive & Boudriga et al. (2010), Ahmad (2013) \\
\hline $\begin{array}{l}\text { Operating } \\
\text { inefficiency (bad } \\
\text { management) }\end{array}$ & Positive & Ghosh (2015), Abdioglu and Aytekin (2016) \\
\hline $\begin{array}{l}\text { Bank capital and } \\
\text { reserves to total } \\
\text { assets, equity-to- } \\
\text { assets ratio }\end{array}$ & Negative & Klein (2013), Makri et al. (2014), Kjosevski and Petkovski (2017) \\
\hline \multirow{2}{*}{$\begin{array}{l}\text { Capital adequacy } \\
\text { ratio }\end{array}$} & Positive & Boudriga et al. (2010) \\
\hline & Negative & Abdioglu and Aytekin (2016), Koju et al. (2018) \\
\hline Bank assets & Negative & Swamy (2012), Curak et al. (2013), Koju et al. (2018) \\
\hline $\begin{array}{l}\text { Credit deposit } \\
\text { ratio }\end{array}$ & Negative & Swamy (2012) \\
\hline Cost of funds & Negative & Swamy (2012) \\
\hline \multirow{2}{*}{$\begin{array}{l}\text { Bank credit } \\
\text { growth rate, loans } \\
\text { to asset ratio }\end{array}$} & Positive & $\begin{array}{l}\text { De Bock and Demyanets (2012), Klein (2013), Ghosh (2015), Abdioglu and } \\
\qquad \text { Aytekin (2016), Kjosevski and Petkovski (2017) }\end{array}$ \\
\hline & Negative & Boudriga et al. (2010) \\
\hline $\begin{array}{l}\text { Foreign currency } \\
\text { loans ratio }\end{array}$ & Positive & Tanasković and Jandrić (2015) \\
\hline $\begin{array}{l}\text { Operating } \\
\text { expenses to total } \\
\text { assets }\end{array}$ & Positive & Swamy (2012) \\
\hline
\end{tabular}




\begin{tabular}{|c|c|c|}
\hline Solvency ratio & Positive & Curak et al. (2013) \\
\hline & Negative & Abdioglu and Aytekin (2016) \\
\hline \multirow[t]{2}{*}{ Return on assets } & Negative & $\begin{array}{l}\text { Boudriga et al. (2010), Curak et al. (2013), Ghosh (2015), Kjosevski and } \\
\text { Petkovski (2017) }\end{array}$ \\
\hline & Positive & Swamy (2012) \\
\hline Return on equity & Negative & Klein (2013), Makri et al. (2014), Kjosevski and Petkovski (2017) \\
\hline Crises & Positive & Kjosevski and Petkovski (2017) \\
\hline \multirow{2}{*}{$N P L_{t-1}$} & Positive & $\begin{array}{l}\text { Curak et al. (2013), Makri et al. (2014), Ghosh (2015), } \\
\text { Kjosevski and Petkovski (2017) }\end{array}$ \\
\hline & Negative & Abdioglu and Aytekin (2016) \\
\hline
\end{tabular}

Source: Author's own elaboration

In another study, De Bock and Demyanets (2012) researched the determinants of NPL in 25 emerging markets during 1996-2010 period employing dynamic panel regression and revealed that economic growth had negative impact on NPL, while exchange rate and credit growth had positive impact on NPL. On the other side, Ahmad (2013) investigated the institutional determinants of NPL in Pakistan during the period 2001-2010 by using regression analysis and found that corruption had positive impact on NPL, while economic growth and lending rate had negative impact on NPL. Messai and Jouini (2013) also investigated the determinants of NPL in 85 banks in Italy, Greece and Spain during the period 2004 and 2008 by using panel regression and found that economic growth had negative impact on NPL, while unemployment and real interest rate had positive impact on NPL. Makri et al. (2014) also investigated the determinants of NPL in 14 euro area member countries using dynamic panel regression during the period 2000-2008 by using dynamic panel regression and found that unemployment, public debt, one lagged value of nonperforming loans had positive impact on NPL, while economic growth, bank capital and reserves to total assets and return on equity had negative impact on NPL.

Curak et al. (2013) researched the determinants of NPL in 69 banks of 10 Southeastern European countries during the 2003-2010 period by employing dynamic panel regression and found that inflation, real interest rate, solvency, one lagged value of NPL had positive impact on NPL, while economic growth, bank size, return on assets had negative impact on NPL. Klein (2013) also researched the determinants behind NPL in 16 Central, Eastern and South-Eastern European countries employing dynamic panel regression over the period 1998-2011 and found that unemployment, inflation, depreciation of currency, loans to asset ratio and lagged values of lending had positive impact on NPL, while equity-to-assets ratio, return on equity, had negative impact on NPL. On the other side, Skarica 
(2014) researched the determinants of NPL in 7 Central and Eastern European countries during 2007-2012 period by employing panel regression and revealed that economic growth had negative impact on NPL, while unemployment and inflation had positive impact on NPL.

Tanasković and Jandrić (2015) investigated the macroeconomic and institutional determinants of non-performing loans in 11 selected countries from Central, Eastern and South-Eastern Europe during the period 2006-2013 by using panel regression and found that there was a negative relationship between NPL and economic growth, financial development, while there was a positive relationship between NPL and foreign currency loans ratio and foreign exchange. On the other hand, Roman and Bilan (2015) investigated the macroeconomic determinants of bank NPL in EU-28 during the 2000-2013 period by using panel regression and found that economic growth and inflation had negative impact on NPL ratio, while unemployment had positive impact on NPL ratio. Ghosh (2015) also researched economic and bank-specific determinants of NPL in the banks of 50 U.S. states and the Columbia district during the period 1984-2013 by employing both traditional and dynamic panel regression and revealed that unemployment, public debt, operating inefficiency, loans-to-asset, loan loss provisioning and lagged values of NPL had positive impact on the NPL, while economic growth, real personal income growth, inflation, housing price index, and return on assets had negative impact on the NPL.

Abdioglu and Aytekin (2016) researched the macroeconomic and bank-specific determinants of NPL with data of 22 banks operating in Turkey during the 2002 2014 period by employing the System GMM and the Difference GMM dynamic panel estimators and revealed that capital adequacy ratio, net interest margin, solvency ratio and lagged values of NPL had negative impact on NPL, while loans, lending interest rate, inefficiency and operating effectiveness had positive impact on NPL. Kjosevski and Petkovski (2017) researched the macroeconomic and bank-specific determinants of NPL in 3 Baltic countries over the period 2005-2014 by employing dynamic panel regression and found that unemployment, one lagged value of domestic credit to private sector (financial development), one lagged value of NPL, growth of gross loans, and the 2009 crisis had positive impact on NPL, while economic growth, one lagged value of equity to total assets, return on assets and return on equity had negative impact on NPL. Pop et al. (2018) conducted a dynamic regression analysis on the determinants of NPL in Romania over the period 2007-2016 and discovered that unemployment, budget deficit, dependency ratio, and total assets positively affected NPL. Lastly, Koju et al. (2018) investigated the internal and macroeconomic determinants of NPL in Nepal over the period 2003-2015 period with regression analysis and re- 
vealed that the export to import ratio, inefficiency and bank size affected NPL positively, while economic growth, inflation, and capital adequacy affected NPL negatively.

\section{Data and Econometric Methodology}

We researched macroeconomic, institutional and bank-specific factors behind NPL in emerging market economies over the period 2000-2013 by employing the System GMM dynamic panel data estimator. Country classification of MSCI (2016) was taken into consideration for the selection of emerging market economies. Furthermore, empirical literature was prioritized in the determination of the variables, but also the availability of data for the sample played role in the process of variable and study period determination.

\subsection{Data}

We researched the macroeconomic, institutional and bank-specific determinants of NPL in two separate models. Bank nonperforming loans to total gross loans was used as dependent variable in both models. In the first model, the impact of macroeconomic and institutional variables on NPL was investigated. On the other side, in the second model, the interaction between bank-specific factors and NPL was analysed. The variables employed in the paper is displayed in Table 2. In this regard, growth rate of real GPD per capita, unemployment rate, annual consumer inflation, general government debt and general government net lending/borrowing and domestic credit to private sector (financial development) are taken for the major macroeconomic variables, while economic freedom index of Heritage Foundation (2016) was taken for institutional quality. Regulatory capital to risk weighted assets, return on assets and equity, noninterest income to total income, and cost income ratio were taken as bank-specific factors. Finally, dummy variables were used in both models to reveal the impact of recent crises on NPL. 
Table 2: Data Description

\begin{tabular}{|c|c|c|c|}
\hline Variables Type & Variables & Symbol & Source \\
\hline & $\begin{array}{l}\text { Bank nonperforming loans to total } \\
\text { gross loans }(\%)\end{array}$ & $N P L$ & World Bank (2016a) \\
\hline \multirow{6}{*}{$\begin{array}{l}\text { Macroeconomic } \\
\text { and institutional } \\
\text { variables }\end{array}$} & Growth of real GDP per capita (\%) & GRW & IMF (2016) \\
\hline & Unemployment rate (\%) & UNEMP & World Bank (2016b) \\
\hline & $\begin{array}{c}\text { Inflation, end of period consumer } \\
\text { prices (\%) }\end{array}$ & INF & IMF (2016) \\
\hline & $\begin{array}{l}\text { General government gross debt (\% of } \\
\text { GDP) }\end{array}$ & PDEBT & IMF (2016) \\
\hline & $\begin{array}{c}\text { General government net lending/ } \\
\text { borrowing ( } \% \text { of GDP) }\end{array}$ & FISCAL & IMF (2016) \\
\hline & Economic freedom index & $\mathrm{EFI}$ & $\begin{array}{l}\text { Heritage Foundation } \\
\qquad(2016)\end{array}$ \\
\hline \multirow{6}{*}{$\begin{array}{l}\text { Bank specific } \\
\text { variables }\end{array}$} & $\begin{array}{l}\text { Domestic credit to private sector (\% } \\
\text { of GDP) }\end{array}$ & DCRD & Čihák et al. (2012) \\
\hline & $\begin{array}{c}\text { Regulatory capital to risk-weighted } \\
\text { assets (\%) }\end{array}$ & RCAP & Čihák et al. (2012) \\
\hline & Return on assets (\%, after tax) & $\mathrm{ROA}$ & Čihák et al. (2012) \\
\hline & Return on equity (\%, after tax) & ROE & Čihák et al. (2012) \\
\hline & Noninterest income to total income (\%) & NONIN & Čihák et al. (2012) \\
\hline & Cost to income ratio (\%) & $\mathrm{CTI}$ & Čihák et al. (2012) \\
\hline
\end{tabular}

Source: Author's own elaboration

We expect the economic growth to affect the NPL negative, because an expanding economy raises the individuals' and firms' income and solvency. On the contrary, a positive relationship between unemployment and NPL is expected since increasing unemployment causes employees to lose their income and this contributes to NPL increase. On the other side, the impact of inflation on NPL is found to be ambiguous. On one hand, increasing inflation decreased the real value of outstanding obligations and thus makes the repayment of loans easier and reduces NPL, but on the other hand, increasing inflation also affects the real income of economic units in case wages are sticky. So inflation raises costs for individuals and thus decreases available funds for the repayment of loans and increases NPL. Deteriorations in public finance also increase NPL through cuts in social expenditures and wages of public employees by governments because decreases in income of individuals and public expenditures also reduce the demand for goods and services of firms. Consequently, decreases in incomes of persons and firms make the repayment of loans difficult and increase NPL. Finally, institutional development represented by economic freedom has a potential to affect NPL negatively by establishing an optimal legal and regulatory environment for banks and also monitoring bank activities closely. 
Furthermore, bank-specific factors are also important for NPL. First, bank capital has negative impact on NPL because banks with relatively low equity tend to raise their exposure to risky loans disregarding the moral hazard considerations (Keeton and Morris, 1987). Banks would like to obtain higher market share and increase their performance in the short run by rapidly increasing loan volume in parallel with loosening the credit standards. Such policies may increase NPL by leading the adverse selection. Profitability proxied by return on assets and equity are also determinative on NPL because banks with low profitability have more incentives to engage in higher risk operations. Diversification proxied by noninterest income to total income in the study is expected to affect NPL negatively since diversification enhances loan quality and decreases NPL. The increasing costs proxied by cost to income ratio in the study also are expected to affect NPL positively because increasing costs encourage banks to undertake higher risk activities and increases NPL.

Moreover, we employed one lagged value of NPL to test the persistence of NPL and expected one lagged value of NPL to have positive impact on NPL. Finally, dummy variable is used in both models to see the impact of the crises on NPL and expected the crises to have positive impact on NPL by way of decreasing economic growth and income of individuals and firms. In the context of econometric analysis, Stata 14.0 statistical package was used for the econometric analysis. The descriptive statistics of the variables in the study were presented in Table 3.

Table 3: Data Summary Statistics

\begin{tabular}{|c|c|c|c|c|c|c|c|c|}
\hline \multicolumn{9}{|c|}{ Model 1} \\
\hline & NPL & GRW & UNEMP & INF & PDEBT & FISCAL & DCRD & $\mathrm{EFI}$ \\
\hline Mean & 6.98 & 3.32 & 8.25 & 5.38 & 48.43 & -2.80 & 62.73 & 61.48 \\
\hline Maximum & 34.40 & 13.57 & 27.20 & 68.49 & 174.95 & 8.36 & 160.12 & 79.00 \\
\hline Minimum & 0.48 & -8.37 & 0.70 & -1.71 & 3.89 & -15.29 & 13.45 & 47.40 \\
\hline Std. Dev. & 6.69 & 3.24 & 5.44 & 5.75 & 26.57 & 3.85 & 40.75 & 6.74 \\
\hline \multicolumn{9}{|c|}{ Model 2} \\
\hline & NPL & & RCAP (\%) & ROA (\%) & ROE (\%) & \multicolumn{2}{|c|}{ NONIN (\%) } & CTI (\%) \\
\hline Mean & 6.62 & & 15.02 & 1.34 & 11.84 & \multicolumn{2}{|c|}{36.25} & 59.00 \\
\hline Maximum & 34.40 & & 30.90 & 20.52 & 178.95 & \multicolumn{2}{|c|}{91.38} & 169.64 \\
\hline Minimum & 0.48 & & 9.90 & -2.84 & -86.02 & \multicolumn{2}{|c|}{3.04} & 22.82 \\
\hline Std. Dev. & 6.29 & & 2.89 & 1.83 & 17.01 & \multicolumn{2}{|c|}{16.10} & 18.17 \\
\hline
\end{tabular}

Source: Author's own elaboration 
Model 1: Brazil, Chile, China, Colombia, Czech Republic, Egypt, Greece, Hungary, India, Indonesia, Korea, Malaysia, Mexico, Peru, Philippines, Poland, Russia, South Africa, Thailand, Turkey, except Qatar, Taiwan and United Arab Emirates.

Model 2: Brazil, Chile, Colombia, Czech Republic, Egypt, Hungary, India, Indonesia, Korea, Malaysia, Mexico, Peru, Philippines, Poland, Russia, South Africa, Thailand, Turkey, except Qatar, Taiwan and United Arab Emirates.

\subsection{Econometric Methodology}

We researched the major determinants behind NPL in the emerging market economies. Our dependent variable is bank nonperforming loans to total gross loans and the explanatory variables compose of macroeconomic, institutional and bank specific variables described in the part of Data. Therefore, we consider the following model:

\section{$N P L=f($ Macroeconomic variables, institutional variables, bank-specific variables)}

In the context of econometric analysis, first stationarity analysis of the variables should be conducted to avoid a possible spurious regression. We employ a dynamic estimator for the regression because the lagged values of the dependent variable NPL are also among our explanatory variables. Therefore, both models will be estimated by the system GMM (generalized method of moments) dynamic panel estimation method The first necessary condition for the use of system GMM estimation method is that the variables used in the analysis should be stationary at their level (Jung and Kwon, 2007:19).

The system GMM estimator, a dynamic panel data estimator, is used with different versions under different assumptions. Arellano and Bond (1991) proposed the Difference GMM estimator (Arellano-Bond estimator) by stating that GMM yields better results in reference to the other estimators when there are normal distribution, heteroscedasticity and measurement errors. Then Arellano and Bover (1995) and Blundell and Bond (1998) developed system GMM dynamic panel data estimator using lagged values of instrumental variables in the difference equations and first differenced values of instrumental variables in the level equations. Furthermore, the system GMM estimator employs a two-stage estimation method considering the error terms with heteroscedasticity, asymptotically more efficient. 


\section{Empirical Analysis}

\subsection{Panel Unit Root Test}

The stationarity of the variables was examined with the unit root tests of Levin et al. (2002) and Im et al. (2003) and the results are displayed in Table 4. The results revealed that all the variables were stationary at the level.

Table 4: Results of Panel Unit Root Tests

\begin{tabular}{lcc}
\hline Variables & Levin et al. $(2002)$ & Im et al. $(2003)$ \\
\hline NPL & $-8.975(0.009)^{*}$ & $-9.534(0.000)^{*}$ \\
\hline GRW & $-4.542(0.000)^{*}$ & $-6.423(0.000)^{*}$ \\
\hline UNEMP & $-6.434(0.012)^{*}$ & $-9.002(0.007)^{*}$ \\
\hline INF & $-5.836(0.000)^{*}$ & $-7.451(0.016)^{*}$ \\
\hline PDEBT & $-7.421(0.002)^{*}$ & $-9.178(0.000)^{*}$ \\
\hline FISCAL & $-4.974(0.006)^{*}$ & $-12.066(0.028)^{*}$ \\
\hline DCRD & $-11.536(0.000)^{*}$ & $-6.821(0.000)^{*}$ \\
\hline EFI & $-9.634(0.024)^{*}$ & $-8.992(0.000)^{*}$ \\
\hline RCAP & $-12.521(0.000)^{*}$ & $-11.845(0.000)^{*}$ \\
\hline ROA & $-6.224(0.005)^{*}$ & $-8.523(0.035)^{*}$ \\
\hline ROE & $-5.489(0.000)^{*}$ & $-6.314(0.009)^{*}$ \\
\hline NONIN & $-4.902(0.003)^{*}$ & $-9.227(0.020)^{*}$ \\
\hline CTI & $-14.563(0.000)^{*}$ & $-13.055(0.003)^{*}$ \\
\hline
\end{tabular}

*stationary at the level

Source: Author's own elaboration based on panel unit root tests

\subsection{Estimation Results of Dynamic Panel Regression Analysis}

We estimated both models with system GMM dynamic panel estimator and the results were displayed in Table 5. The accuracy of the results for both models was investigated by Wald, Sargan (1958) and Arellano-Bond (1991) tests and the results also were displayed in Table 5 . Wald $\chi^{2}$ test investigates whether the model as a whole is statistically significant and the results of the test indicated the variables in both models were significant as a whole. On the other hand Sargan $\chi^{2}$ test investigates whether the instrumental variables in the models are valid or not. The null hypothesis (over-identifying restrictions are valid) was rejected considering the results of the test and it was concluded that the instrumental variable was valid. Finally, Arellano-Bond test examines whether autocorrelation 
problem in the models or not. We tested the existence of autocorrelation problem at first and second-order autocorrelation, the test statistics of $\mathrm{AR}(1)$ were found to be negative and significant and the test statistics of $\operatorname{AR}(2)$ were found to be insignificant. So there was autocorrelation at first-order, but there was not autocorrelation at second-order.

The estimation results of the first model showed that unemployment, public debt, one lagged value of NPL had positive impact on NPL, while economic growth, inflation, general government net lending/borrowing and economic freedom (institutional development) had negative impact on the NPL. Economic freedom (12\%), one lagged value of NPL (11\%), unemployment (7\%) and public debt (\%7) had the largest impact on NPL respectively in terms of the coefficients.

Table 5: Results of System GMM Dynamic Panel Estimation

\begin{tabular}{|c|c|c|c|}
\hline \multicolumn{2}{|c|}{ Model 1} & \multicolumn{2}{|c|}{ Model 2} \\
\hline Dependent variable: NPL & Coefficient ( $p$-value) & Dependent variable: NPL & Coefficient ( $p$-value) \\
\hline $\operatorname{NPL}(-1)$ & $0.114607(0.000)^{*}$ & DCRD & $0.017441(0.000)^{*}$ \\
\hline GRW & $-0.02946(0.025)^{*}$ & $\operatorname{NPL}(-1)$ & $0.107828(0.000)^{*}$ \\
\hline UNEMP & $0.079390(0.000)^{*}$ & RCAP & $-0.115744(0.000)^{*}$ \\
\hline INF & $-0.020073(0.015)^{*}$ & $\mathrm{ROA}$ & $-0.093931(0.036)^{*}$ \\
\hline DEBT & $0.072728(0.000)^{*}$ & $\mathrm{ROE}$ & $-0.049981(0.000)^{*}$ \\
\hline FISCAL & $-0.011151(0.011)^{*}$ & NONIN & $-0.121127(0.018)^{*}$ \\
\hline $\mathrm{EFI}$ & $-0.126779(0.005)^{*}$ & $\mathrm{CTI}$ & $0.114606(0.000)^{*}$ \\
\hline Dummy & $0.122993(0.000)^{*}$ & Dummy & $0.147231(0.003)^{*}$ \\
\hline No of observations & 260 & No of observations & 234 \\
\hline No of cross-sections & 20 & No of cross-sections & 18 \\
\hline Wald $x^{2}$ & $123.45(0.000)$ & Wald $x^{2}$ & $167.98(0.002)$ \\
\hline Sargan $x^{2}$ & $4.321(0.781)$ & Sargan $x^{2}$ & $3.642(0.219)$ \\
\hline$A R(1)$ & $-21.892(0.007)$ & $A R(1)$ & $-34.731(0.028)$ \\
\hline $\operatorname{AR}(2)$ & $-1.734(0.163)$ & $\operatorname{AR}(2)$ & $-1.962(0.173)$ \\
\hline
\end{tabular}

* statistically significant at $5 \%$ significance level

Source: Author's own elaboration based on regression analysis

On the other hand the estimation results of the second model showed that domestic credit to private sector (credit growth), cost to income ratio and one lagged value of NPL had positive impact on NPL, while regulatory capital to risk-weighted assets, return on assets and equity and noninterest income to total income had negative impact on NPL. Noninterest income to total income (12\%), regulatory capital to risk-weighted assets (11\%), cost to income ratio (11\%), one lagged value 
of NPL (10\%) and return on assets (9\%) had the largest impact on NPL respectively in terms of the coefficients. Finally the variables representing the recent financial crises in both models revealed that crises had positive impact on the NPL and the crises led a 11\% increase in NPL in Model 1 and a $14 \%$ increase in NPL in Model 2 in case of $1 \%$ change in the dummy variable.

The empirical analysis revealed that bank specific factors such as credit growth, cost to income ratio, regulatory capital to risk-weighted assets, bank profitability and equity and noninterest income to total income were significant determinants of NPL. However, the macroeconomic factors represented by economic growth, unemployment, public debt, and inflation, as well as financial crises, were significant determinants of NPL. Further, institutional development represented by economic freedom index had a significant impact on NPL. In this context, not only bank-specific factors such as bank equity, regulatory capital, profitability, and risk management are the important factors behind NPL, but also macroeconomic factors and institutional development. So, stability in macroeconomic environment and improvements in institutional development also may contribute to control NPL within reasonable values.

\section{Conclusion}

This study researched the macroeconomic and bank-specific determinants of NPL in emerging market economies during the 2000-2013 period by employing the system GMM dynamic panel data estimator. The results revealed that unemployment, public debt, and one lagged value of NPL had a positive impact on NPL, while economic growth, inflation, general government net lending/borrowing, and economic freedom (institutional development) had a negative impact on NPL. On the other side, domestic credit to private sector (credit growth), cost to income ratio, and one lagged value of NPL had a positive impact on NPL, while regulatory capital to risk-weighted assets, return on assets and equity and noninterest income to total income had a negative impact on NPL. Furthermore, the dummy variable representing the recent financial crisis denoted that crises have a positive impact on NPL.

The findings of the study were found to be consistent with the relevant literature. Furthermore, the study revealed that not only bank specific characteristic but also macroeconomic factors and institutional development are important factors for efficient and sound functioning of the banking sector. Therefore, macroeconomic policy-makers and government executives design optimal institutional and economic environment for efficient functioning of the banking sector. 


\section{References}

1. Abdioglu, N., Aytekin, S. (2016). Takipteki Kredi Oranını Etkileyen Faktörlerin Belirlenmesi: Mevduat Bankaları Üzerinde Bir Dinamik Panel Veri Uygulaması. İşletme Araştırmaları Dergisi, 8(1), 538-555.

2. Ahmad, F. (2013). Corruption and Information Sharing as Determinants of Non-Performing Loans. Business Systems Research, 4(1), 87-98. doi:10.2478/ bsrj-2013-0008

3. Arellano, M., and Bond, S. (1991). Some Tests of Specification for Panel Data: Monte Carlo Evidence and an Application to Employment Equations. Review of Economic Studies, 58, 277-98.

4. Arellano, M., and Bover, O. (1995). Another Look at the Instrumental Variable Estimation of Error-Components Models. Journal of Econometrics, 68, 29-51. doi:10.1016/0304-4076(94)01642-D

5. Blundell, R., and Bond, S. (1998). Initial Conditions and Moment Restrictions in Dynamic Panel Data Models. Journal of Econometrics, 87, 115-143. doi:10.1016/S0304-4076(98)00009-8

6. Boudriga, A., Taktak, N.B., Jellouli, S. (2010). Bank Specific, Business and Institutional Environment Determinants of Banks Nonperforming Loans: Evidence from MENA Countries. Economic Research Forum Working Papers, No.547.

7. Čihák, M., Demirgüç-Kunt, A., Feyen, E., Levine, R. (2012). Benchmarking Financial Systems Around the World. World Bank Policy Research Working Paper 6175, World Bank, Washington, D.C.

8. Curak, M., Pepur, S., Poposki, K. (2013). Determinants of Non-performing Loans - Evidence from Southeastern European Banking Systems. Banks and Bank Systems, 8(1), 45-53.

9. De Bock, R., Demyanets, A. 2012. Bank Asset Quality in Emerging Markets: Determinants and Spill-overs. IMF Working Paper, WP/12/71.

10. Ghosh, A. (2015). Banking-Industry Specific and Regional economic Determinants of Non-performing Loans: Evidence from US States. Journal of Financial Stability, 20, 93-104

11. Heritage Foundation (2016). Index of Economic Freedom. Available at http:// www.heritage.org/index/

12. IMF (2016). World Economic Outlook Database. Retrieved January 31, 2016, from https://www.imf.org/external/pubs/ft/weo/2015/02/weodata/index. aspx

13. Im, K.S., Shin, M.H., Shin, Y. (2003). Testing for Unit Roots in Heterogeneous Panels. Journal of Econometrics, 115, 53-74. DOI: 10.1016/S03044076(03)00092-7 
14. Jung, H., and Kwon, H. (2007). An Alternative System GMM Estimation in Dynamic Panel Models, Hi Stat Discussion Paper No. 217, Hitotsubashi University.

15. Keeton W.R., Morris, C.S. 1987. Why do Banks' Loan Losses Differ. Economic Review, 3-21.

16. Kjosevski, J., Petkovski, P. (2017). Non-performing Loans in Baltic States: Determinants and Macroeconomic Effects. Baltic Journal of Economics, 17(1):25-44. doi:10.1080/1406099X.2016.1246234

17. Klein, N. (2013). Non-performing Loans in CESEE: Determinants and Impact on Macroeconomic Performance. IMF Working Paper, WP/13/72.

18. Koju, L., Koju, R., Wang, S. (2018). Macroeconomic and Bank-Specific Determinants of Non-Performing Loans: Evidence from Nepalese Banking System. Journal of Central Banking Theory and Practice, 7(3):111-138. doi:10.2478/ jcbtp-2018-0026

19. Levin, A., Lin, C.F., Chu, C.S.J. (2002). Unit Root Tests in Panel Data: Asymptotic and Finite Sample Properties. Journal of Econometric, 108:1-22. doi:10.1016/S0304-4076(01)00098-7

20. Louzis, D.P., Vouldis, A.T., Metaxas, V.L. (2012). Macroeconomic and Bankspecific Determinants of Non-performing Loans in Greece: A comparative Study of Mortgage, Business and Consumer Loan Portfolios. Journal of Banking \& Finance, 36(4):1012-1017. DOI: 10.1016/j.jbankfin.2011.10.012

21. Makri, V., Tsagkanos, A., Bellas, A. (2014). Determinants of Non-Performing Loans: The Case of Eurozone. Panoeconomicus, 2014/2, 93-206. doi:10.2298/ PAN1402193M

22. Messai, A.S., Jouini, F. (2013). Micro and Macro Determinants of Non-performing Loans. International Journal of Economics and Financial Issues, 3(4), 852-860.

23. MSCI. 2016. Market classification, https://www.msci.com/market-classification (31.01.2016)

24. Petkovski, M., Kjosevski, J. (2014). Does Banking Sector Development Promote Economic Growth? An Empirical Analysis for Selected Countries in Central and South Eastern Europe. Economic Research, 27(1), 55-66. doi:10.1 080/1331677X.2014.947107

25. Pop, I.D., Chicu, N., Răduțu, A. (2018). Non-performing Loans Decision Making in the Romanian Banking System. Management \& Marketing Challenges for the Knowledge Society. 13(1), 761-776. doi: 10.2478/mmcks-2018-0004

26. Roman, A., Bilan, I. (2015). An Empirical Analysis of the Macroeconomic Determinants of Non-performing Loans in EU-28 Banking Sector. Revista Economică, 67(2), 108-127.

27. Sargan, J. (1958). The Estimation of Economic Relationships using Instrumental Variables. Econometrica, 26(3):393-415. DOI: 10.2307/1907619 
28. Skarica, B. (2014). Determinants of Non-performing Loans in Central and Eastern European Countries. Financial Theory and Practice, 38(1), 37-59.

29. Stijepović, R. (2014). Recovery and Reduction of Non-Performing Loans Podgorica Approach. Journal of Central Banking Theory and Practice, 3(3): 101-108. doi: 10.2478/jcbtp-2014-0017

30. Swamy, V. (2012). Impact of Macroeconomic and Endogenous Factors on Non-performing Bank Assets. International Journal of Banking and Finance, 9(1):27-47.

31. Tanasković, S., Jandrić, M. (2015). Macroeconomic and Institutional Determinants of Non-performing Loans. Journal of Central Banking Theory and Practice, 2015/1:47-62. doi: 10.1515/jcbtp-2015-0004

32. World Bank (2016a). Bank nonperforming loans to total gross loans (\%). Available at http://data.worldbank.org/indicator/FB.AST.NPER.ZS/countries

33. World Bank (2016b). Unemployment, total (\% of total labor force). Available at http://data.worldbank.org/indicator/SL.UEM.TOTL.ZS 